\title{
A Real Options Model for Evaluating Investments in the Guarulhos Airport Concession Program
}

\author{
João Carlos Félix Souza ${ }^{1,2}$, Matheus Martins Silva ${ }^{1}$, Luiza Moury Fernandes ${ }^{1}$, Guilherme Nóbrega ${ }^{1}$, \\ Felipe Moutinho 1 \\ ${ }^{1}$ Faculty of Technology, University of Brasilia - UnB, Brasilia, Brazil \\ ${ }^{2}$ Graduate Program in Applied Computing - PPCA, University of Brasília - UnB, Brasília, Brazil
}

\section{Email address:}

jocafs@unb.br (J.C. F. Souza), matheusmartinsilva8@gmail.com (M. M. Silva), luizamoury@gmail.com (L. M. Fernandes), gui.nobrega95@gmail.com (G. Nóbrega),moutinhoofelipe@gmail.com (F. Moutinho)

\section{To cite this article:}

João Carlos Félix Souza, Matheus Martins Silva, Luiza Moury Fernandes, Guilherme Nóbrega, Felipe Moutinho. A Real Options Model for Evaluating Investments in the Guarulhos Airport Concession Program. American Journal of Theoretical and Applied Business.

Vol. 5, No. 3, 2019, pp. 47-52. doi: 10.11648/j.ajtab.20190503.11

Received: August 6, 2019; Accepted: September 3, 2019; Published: September 24, 2019

\begin{abstract}
The Brazilian government began, in 2012, the program of concessions of the administration of Brazilian airports in order to improve customer service through private capital. One of the main subjects of this concession plan was the airport of Guarulhos, in the state of São Paulo (Brazil), which is the largest airport in the country, responsible on average for over 20,000 flights and transporting approximately 4 million passengers per month. Concessions of this scale demand large investments, which in turn can result in greater uncertainties regarding future cash flows. In certain cases, the NPV (Net Present Value) of these investments may become negative, which does not necessarily mean that the undertaking is unfeasible, or that it should not be encouraged. Changes in the overall economic scenario can subsequently lead to updated results in the expected cash flow, making the investment viable. One of the ways to evaluate a project under an uncertain scenario is to use the Real Options model as a strategic complement to cash flow analysis. This article presents an application to calculate the value of the expansion option for the Guarulhos international airport. For the models of uncertainty related to passenger load and flight volume, the value of the expansion option using the Black-Scholes-Merton model is calculated. The article concludes with the recommendation for the expansion to be carried out on a 4-year horizon, which in this period results in a positive strategic NPV, in addition to optimizing the utilization of the airport's terminal capacity.
\end{abstract}

Keywords: Airports, Concessions, NPV, Real Options, Black-Scholes-Merton Model

\section{Introduction}

The rates of economic development experienced by Brazil in recent years, in addition to the major sporting events hosted by the country, have resulted in an increasing need for travel, and therefore a considerable expansion of the country's airline industry. In 2014, due to the World Cup, more than 100 million passengers were transported, an important number that made the country the 12th largest air market in the world [1]. As of July 2019, it will typically serve over 20,000 flights and 4 million passengers per month.

The large number of transported passengers demands an adequate airport infrastructure that is able to serve travelers quickly and efficiently. However, due to a previous lack of investment, the country's airport capacity has not increased at the same rate as the growing demand. This has lead to an overload of existing infrastructure, which is not able to deliver adequate air service to consumers [1].

To increase the quality and efficiency of airport services in Brazil, a modernization of facilities and infrastructures is needed. However, these improvements require large sums of capital that the government presently is not able to produce. It is in this context that privatization emerges as a viable alternative for financing the necessary improvements to the nation's airport infrastructure [1].

The construction of new airport terminals involves both millions of dollars of investment and a high level of political and regulatory influence. This context brings much 
uncertainty to the projection of future cash flows. Thus, it is difficult to assess the viability of such a project using only traditional methods such as Net Present Value (NPV). However, it is usual for projects of this nature to incorporate several options which may somehow protect investors from potential losses [2].

According to the studies [3, 4], if the flexibilities of a real options model are not contemplated, the evaluation may result in a negative NPV, in which case the project's execution would be considered infeasible. When utilizing the real options model, this flexibility mechanism can be observed by taking into account a dynamic process, possibly resulting in a change of NPV, and thus making the project viable.

This paper aims to identify and analyze the application of real options through the Black-Scholes-Merton method, as a means of evaluating the viability of investments in the Guarulhos airport's air terminal expansion in São Paulo, Brazil.

To fulfill its objectives, the work is divided into sections defined as Theoretical Review, Methodology, Results and Discussion, Conclusion, and References. The first part deals with the theoretical framework, describing the evaluated scenario. Subsequently, the base methodology of the real options model is described, followed by the analysis for the evaluation of Guarulhos Airport's expansion investments, made in 2012.

\section{Theoretical Review}

\subsection{Brazilian Airport Management}

According to the Brazilian Aeronautics Code, Law No. 7.565 / 86 art. 31, airports are classified as public aerodromes that possess the facilities and infrastructure required to support aircraft operations and the loading and unloading of people and cargo. With regards to their scope of operations, they can be classified as international (when air traffic originates from, or is destined to, foreign countries), national (when operations are restricted to national territory), and regional, all of which are of national interest [5].

The Brazilian Executive was authorized, by Law No. 5,862, of December 12, 1972, to set up a public airport management organization in Brazil. INFRAERO is a public company whose purpose is to implement, administer, and to industrially and commercially operate the nation's airport and air navigation support infrastructure, as well as to perform any activities conferred by the Civil Aviation Secretariat of the Presidency of the Republic (SAC-PR). Until 2010, the company was responsible for managing all major airports, which altogether represent $97 \%$ of Brazil's passenger and cargo flights [5].

As seen in Figure 1, from 2004 to 2017 there was a 173\% growth in passenger volume in the nation's airports. However, available infrastructure did not keep up with this expansion, and thus difficulties related to saturation, limitations, and structural bottlenecks resulted in the concession of airports to the private sector [6].

Evolution of the amount of paying and transported passengers in Brazil

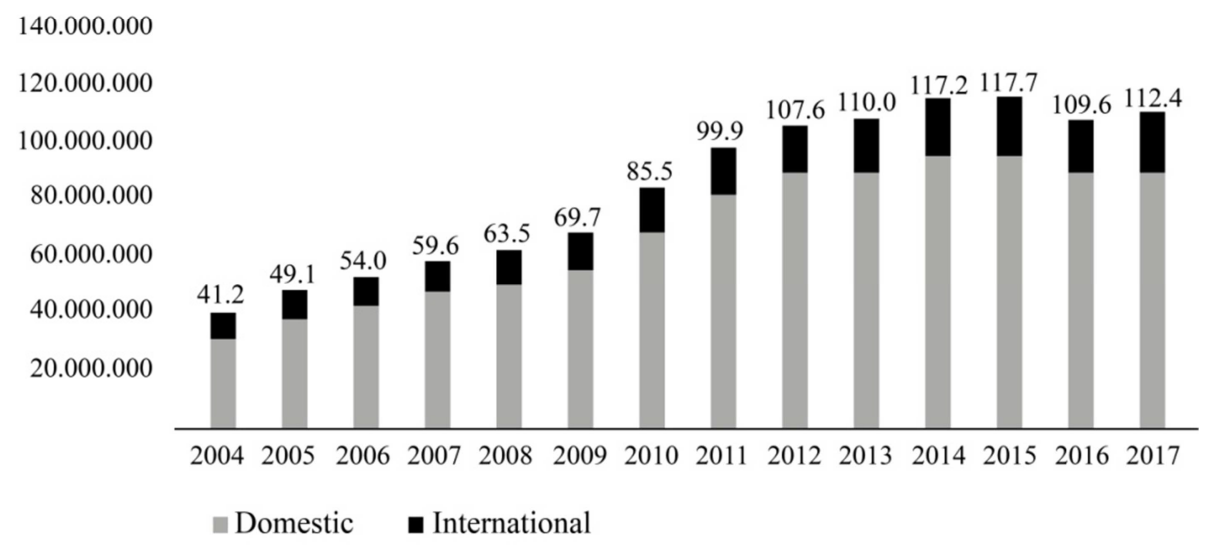

Figure 1. Evolution of the amount of paying and transported passengers in Brazil. Source: [7].

\subsection{Airport Concessions in Brazil}

The study [8] cites three forms of possible airport management by private sector initiatives: outsourced management contracts, long-term leases, and sales. The author lists five broad categories as the potential benefits of airport privatization: I. Increased efficiency; II. Additional operating income to the private sector; III. Increases in consumer amenities; IV. Decreased risk of "white elephants"; V. Income from leases or sales.

Decree 7,624 of November 22, 2011 allowed for the exploration of Brazilian airports by means of concessions. The law provides for the conditions of "private exploitation of airport infrastructure by concession" (art. 1). In 2012, the Federal Government initiated the Brazilian airport concession program, in two initial lots with the following airports: Brasilia (BSB), Rio de Janeiro / Galeão (GIG), Belo Horizonte / Confins (CNF), Campinas / Viracopos (VCP), Guarulhos (GRU) and Natal / São Gonçalo do Amarante (NAT). In this work, the Guarulhos Airport concession program will be used as a case study.

As shown in Figure 2, Guarulhos Airport is the busiest in 
Brazil, representing $11 \%$ of the country's flights. It has an annual revenue of approximately US\$ 500 million, with 43 million users and 293,000 flights. The airport was awarded to the South African company Airport Company South Africa
(ACSA), which operates 11 airports in South Africa and one in India, with the purpose of expanding, maintaining, and operating the Airport Complex infrastructure [7].

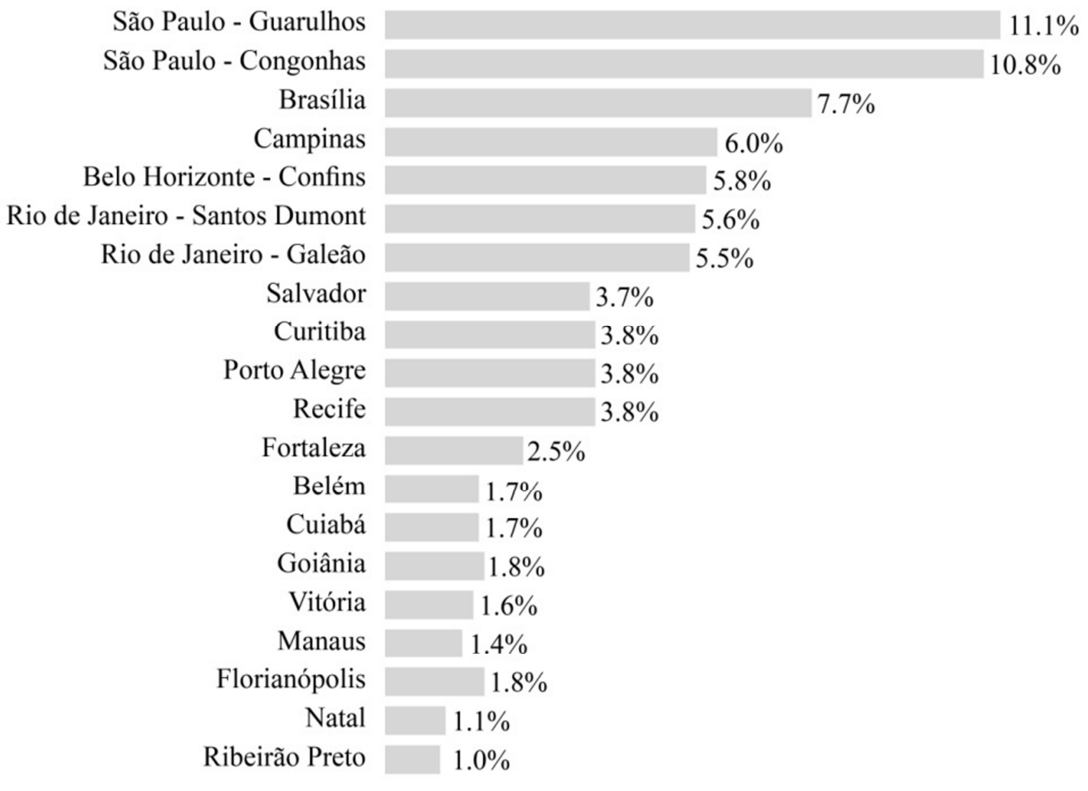

Figure 2. Participation of the top 20 airports in the number of takeoffs - domestic market, 2017. Source: [7].

\section{Method}

This section presents the steps that were developed in order to achieve the objectives set for this study. According to the study [9], the methodology comprises the set of steps or processes that facilitate both the approach to problems and the search for answers. Therefore, in order to apply the Real Options Model using the Black and Scholes [10] method to evaluate concession investments at Guarulhos Airport, the following methodology was defined, as shown in Figure 3.

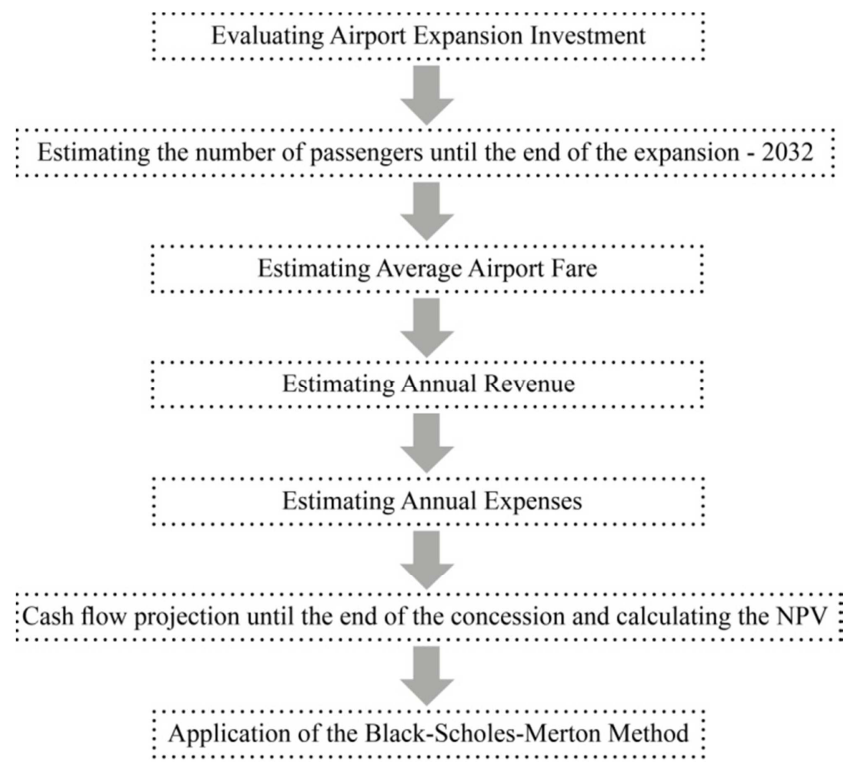

Figure 3. Research Methodology.
The applied research is oriented towards generating the required knowledge for assisting in decision making. For the study [11], this type of research focuses on quantitative analysis. Thus, this paper seeks to present a technique for assessing the risk of an investment. With this study, the best options are analyzed in order to choose the ideal time to realize the concession investment.

This paper, therefore, was developed following the seven steps illustrated in Figure 3. Initially there is an analysis of the actual airport scenario through the collected data, seeking to project future demand until the end of the concession period, scheduled for 2032, and thus project a cash flow for the same period by analyzing the average airport fare. Based on this and the estimated income and expenses, the necessary data is collected for the calculating the Net Present Value (NPV), which was performed through a Microsoft Excel spreadsheet [12].

Following the calculation of the NPV, it is possible to determine the present value of future investments at the airport, discounted at an appropriate interest rate, minus the cost of the initial investment needed to expand the concession.

The work [13] addresses the issue of optimal timing and the investment's opportunity value by utilizing the principles of option valuation. The key issue is choosing the right time to exercise an investment option. To address this problem, it becomes necessary to know the impact of uncertainty on the value of the investment option [14]. As such, the proposed model is evaluated by means of the following general equation:

Strategic NPV = Traditional NPV + RO (Real Options) (1) 
The Black and Scholes [10] method will be utilized for analyzing the concession's investments by generating partial differential equations that are linked to the cash inflows and outflows used in the traditional NPV calculation. These changes in the cash flow will function as random scenarios.

According to the study [15], an application of the Black-Scholes-Merton model assumes that the price of assets evolves according to a Brownian geometric movement, used to model financial and economic variables. Thus, the definition of the options is made from factors that make up the NPV calculation, such as the growth in demand and yearly profit, when the movement of these factors causes the Net Present Value to produce several results. This is fundamental to the investment-related risk analysis by means of evaluating real options, as is done within the Black-Scholes-Merton method [16]. The result is given as the best time to begin the expansion of the airport in question.

\section{Results and Discussion - Application in the Expansion of Guarulhos Airport}

This section presents the equations for the Black-Scholes-Merton model, and simulates the value of the option for postponing any future expansion of the Guarulhos airport.

\subsection{The Black-Scholes-Merton Model}

The Black-Scholes-Merton model was developed by Fisher Black, Robert Merton and Myron Scholes in the mid-1970s. Black and Scholes [10] developed their ideas in a paper entitled "The pricing of options and corporate liabilities". Author [17] deals with the subject in the article entitled "Theory of rational option pricing", published in the same year.

The fundamental basis of the Black-Scholes-Merton model is the idea of derivative contracts. They can be understood as contracts whose prices derive from an underlying asset. Thus, an option contract is a derivative that gives the right (but not obligation) to one of the parties (which pays an amount for this right) to buy (or sell) an asset at a specified price, at a future date, until the maturity of the contract [16].

Option contracts are characterized by two types of operations:

1. Call: The option to purchase a particular asset at a pre-set price.

2. Put: The option to sell a certain asset at a predetermined price.

An options contract may also characterized by specifying the exercise period, in which case the most common types are:

1. The European Option: A contract in which the option can only be exercised at maturity.

2. The American Option: A contract under which the option may be exercised at any time during the term of the contract.

Therefore, the objective is to determine the amount that must be presently paid for an option contract, in order to be entitled to buy (sell) an asset that is currently worth S, at a future date, for a price $\mathrm{X}$.

It is known that a call option on a given date $t$ has its value defined as:

$$
\mathrm{Ct}=\max (\mathrm{St}-\mathrm{X} ; 0)
$$

and a put option on a given date $\mathrm{t}$ has its value defined as:

$$
\mathrm{Pt}=\max (\mathrm{X}-\mathrm{St} ; 0)
$$

Given that $\mathrm{Ct}$ is the price of a call at time $\mathrm{t}, \mathrm{Pt}$ is the price of a put at time $t, X$ is the strike price and $S t$ is the price of the asset at time $\mathrm{t}$.

The Black-Scholes-Merton model assumes that the option can only be exercised on a pre-set date. Therefore, it utilizes the value of European options. The equations for a call option are:

$$
\mathrm{C}=\mathrm{S} 0 * \mathrm{~N}(\mathrm{~d} 1)-\mathrm{Xe}^{-\mathrm{Rf} * \mathrm{~T}} * \mathrm{~N}(\mathrm{~d} 2)
$$

Where $\mathrm{d} 1$ and $\mathrm{d} 2$ are given by the following expressions, respectively:

$$
\begin{gathered}
d 1=\ln \left(\frac{S 0}{x}\right)+\left(R F+0,5 \delta^{2}\right) * T \\
d 2=d 1-\delta \sqrt{T}
\end{gathered}
$$

The variable $N($.) represents the accumulated normal function whose value is tabulated and easily verifiable [18]. $C_{0}$ is the value of the call option, $\mathrm{S}_{0}$ is the current share price, $X$ is the price of exercising the option, $\mathrm{T}$ is the time at which the option may be exercised, $\sigma$ is the standard deviation of the expected return, and RF is the risk-free return rate. The model can be represented as in Table 1:

Table 1. Symbology of the variables in the Black-Scholes-Merton model.

\begin{tabular}{ll}
\hline Variable & Symbol \\
\hline Current price of the stock or underlying asset & $\mathrm{S}_{0}$ \\
Option strike price & $\mathrm{X}$ \\
Time until option exercise & $\mathrm{T}$ \\
Standard deviation of the expected return & $\sigma$ \\
Risk-free return rate over the option's period & $\mathrm{R}_{\mathrm{F}}$ \\
\hline
\end{tabular}

Source: [16]

\subsection{Simulation}

To analyze the problem at hand, the first step was to determine an adequate demand forecast that would demonstrate the future panorama of passenger flow at Guarulhos airport. Thus, as a base demand forecast, a study conducted in 2017 by the Brazilian Ministry of Transport, Ports and Civil Aviation was utilized. This study presents in detail the methodology and steps used to forecast passenger demand at several Brazilian airports by the year 2037 (including Guarulhos).

The base material utilizes two scenarios for forecasting positive and neutral. In this study only the neutral scenario was considered, as it is the most conservative in its predictions. Table 2 presents the demand forecast for the 2019 - 2032 period, the latter being the final year of the airport concession: 
Table 2. Demand forecast scenario for Guarulhos Airport (2019 - 2032).

\begin{tabular}{lll}
\hline Year & Forecast & Utilization \\
\hline 2019 & 43.626 .099 & $87,25 \%$ \\
2020 & 45.021 .767 & $90,04 \%$ \\
2021 & 46.417 .434 & $92,83 \%$ \\
2022 & 47.813 .102 & $95,63 \%$ \\
2023 & 49.208 .769 & $98,42 \%$ \\
2024 & 50.604 .437 & $101,21 \%$ \\
2025 & 52.000 .104 & $104,00 \%$ \\
2026 & 53.395 .771 & $106,79 \%$ \\
2027 & 54.791 .439 & $109,58 \%$ \\
2028 & 56.187 .106 & $112,37 \%$ \\
2029 & 57.582 .774 & $115,17 \%$ \\
2030 & 58.978 .441 & $117,96 \%$ \\
2031 & 60.374 .108 & $120,75 \%$ \\
2031 & 61.769 .776 & $123,54 \%$ \\
\hline
\end{tabular}

Source: adapted from [7]

In the "Utilization" field, airport utilization was calculated based on the current capacity of 50 million passengers per year. This demonstrates that, in the short term, the airport will be at its maximum operational capacity and, therefore, will require expansion efforts.

Subsequently, it was necessary to determine the average airport fare price. Using historical data from domestic and international passenger flights, it was possible to note that, in the past 10 years, the proportion between national and international passenger flights has remained stable, with $64 \%$ of the terminal's users originating from domestic flights.

With adjusted values of domestic and international fares at US\$ 7.80 and US\$ 30.50 , respectively, it was possible to calculate a weighted average fare estimate of US\$ 15.80 per passenger.

Based on the income statements available on the airport's official website, it was possible to forecast its estimated operating costs up to the year 2031. With this data, a cash flow was made, taking into consideration the investment for expanding the airport, of around US\$ 500 million (estimated by the terminal's management company), aimed at increasing the operating capacity to 60 million passengers per year (which is the minimum capacity that the concessionaire must deliver to the airport at the end of the concession period).

It is assumed that the actual option expires in 4 years, which is when the terminal utilization rate is expected to exceed $95 \%$. The Black-Scholes-Merton model can be used to determine the value of the hold option, as it is a European deferral option with a fixed exercise date. Table 3 below simplifies the parameters of the proposed model:

Table 3. Simulation (summary of the values for the Black-Scholes-Merton model).

\begin{tabular}{lll}
\hline$r_{F}=$ & Risk-free return rate & $=6,5 \%$ per annum \\
$\tau=$ & Time (in years) until option exercise deadline & $=4$ \\
$\mathrm{X}=$ & Cost for implementing the project & $=$ US\$ 0.5 billion \\
$\mathrm{S}_{0}=$ & Current value of the project & $=0.0169$ \\
$\sigma^{2}$ & Variance of the project's expected return & $=0.48$ billion \\
$d_{1}$ & & $=0.57$ \\
$d_{2}$ & & $=0.61$ \\
$\mathrm{~N}\left(\mathrm{~d}_{1}\right)$ & & $=0.7157$ \\
$\mathrm{~N}\left(\mathrm{~d}_{2}\right)$ & & $=0.6179$ \\
\hline
\end{tabular}

Source: Authors

The following parameters were defined as inputs for the Black-Scholes-Merton model: The risk-free rate adopted was the Brazilian Selic rate, equal to $6.5 \%$ per annum. The exercise price was made equivalent to the project's construction cost of US\$ 500 million (in 2019).

The current share price (object asset) is approximated by the present value of expected future cash flows from the enterprise, estimated in 2019 at US\$ 482,813,645.25 (the discount rate is set as the risk-free rate). The expected return variance of the venture is used to represent the variance of the stock return rate in the Black-Scholes-Merton model, assumed to be 0.0169 per annum.

The variables $\mathrm{d} 1$ and $\mathrm{d} 2$ were calculated using the previously detailed formulas, and the results obtained were, respectively: 0.57 and 0.61 . With these results, and using a probability distribution table, it was possible to find the values of $\mathrm{N}(\mathrm{d} 1)$ and $\mathrm{N}(\mathrm{d} 2)$ which are, respectively: 0.7157 and 0.6179 .

According to the ANAC spreadsheet [7], the traditional NPV calculation result was negative, with US\$ $56,317,696.62$ in the 2017 base year.
Once all the previously mentioned data was obtained, it was possible to calculate the value of the real option using the call equation of the Black-Scholes-Merton model. The value found was US\$107,333,338.51. As the calculated traditional NPV of the project is - US\$ 56,317,696.62; the net value of the wait option, or the strategic NPV according to (2), is the difference between both values (US\$ 107,333,338.51 US\$ 56,317,696.62), equal to US\$ 51,015,641.89.

It is thus recognized that the venture possesses a negative traditional NPV, although it can be realized in the near future, considering the 4-year horizon for saturation of the airport's capacity. Thus, it is possible to wait for better economic conditions considering the national macroeconomic scenario.

\section{Conclusion}

Concession projects are fundamental to the development of national infrastructure. In the air transportation industry this reality is no different, and in recent years Brazil has been experimenting with various concession projects in this sector.

In the evaluated case study presented in this paper, the 
Guarulhos airport concessionaire is given the opportunity to expand the airport's capacity. The main reason for this expansion is the fact that the airport's operational limits will be reached in the near future. There is also a need to fulfill the concessionaire's contractual obligations as stipulated in the concession agreement, as the main legal provision is for an expansion of the airport's passenger capacity.

However, as observed in the evaluated case study, the resulting traditional NPV of the new investment is negative. Therefore, the investment must be made in the near future. The value of postponing the expansion can be obtained by applying the real options approach, as exemplified in this article by the Black-Scholes-Merton model. The real option value may be considered as being the expected initial value of the expansion.

Therefore, it is recommended that the airport's expansion project be carried out within 4 years, at which point the airport's operational capacity is expected to be reached. Thus, a real profit is expected for the concessionaire from implementing the investment.

Lastly, as a suggestion for future studies, it can be reccommended that an analysis be performed with an approach somewhat contradictory to this study, by evaluating a different situation to determine the strategic value, such as an option of abandonment or an option of expansion in different periods, with either the Black-Scholes-Merton approach, a binomial decision tree model, or a Monte Carlo simulation.

\section{References}

[1] ANAC, "Guarulhos (SP)" Available in: (https://www.anac.gov.br/assuntos/paginas-tematicas/concesso es/guarulhos). Acessed in: July 10, 2019.

[2] Copeland, T. and V. Antikarov, "Opções reais: um novo paradigma para reinventar a avaliação de investimentos". Rio de Janeiro, Editora Campus, 2001.

[3] Adetunji, O. M. and A. A. Owolabi, "Real Options and Government Supports to Infrastrucutre Investments: An Empirical Study. Journal of Modern Accounting and Auditing", v. 13, n. 5, p. 196-215. DOI: 10.17265/1548-6583/2017.05.002, 2017.

[4] Taneja, P., M. E. Aartsen, J. A. Annema, M. van Schuylenburg, "Real Options for Port Infrastructure Invesments. Shenzhen, China. Infrastructure Systems and Services: Next Generation Infrastructure Systems for Eco-Cities (INFRA)", 2010 Third International Conference - Shenzhen/ China, 2010.
[5] IPEA, "IPEA divulga estudos sobre aeroportos no Brasil - Nota técnica do Instituto trata de estratégias e investimentos no setor aeroportuário no Brasil" Available in: (https://www.ipea.gov.br/portal/index.php?option=com_conte nt\&view $=$ article $\&$ id $=8032 \&$ Itemid $=8$ ). Acessed in: march 5, 2019.

[6] Paiva, Izabela Davanzo, "Concessão de aeroportos no Brasil: A transferência da Gestão do Aeroporto de Confins para a Iniciativa Privada". Rem: Universidade Federal de Alfenas, 2015.

[7] ANAC, "Anuário do Transporte Aéreo 2017". Rem: Site Anac. 2018.

[8] Poole Jr., R. W, "Transportation Infrastructure Finance 2012". Reason Foundation, April 8, 2013.

[9] Moreira, V. R., "Gestão dos Riscos do Agronegócio no Contexto Cooperativista". 208 f. Tese (Doutorado em Administração de Empresas) - Fundação Getúlio Vargas, São Paulo, 2009.

[10] Black, F. and M. Scholes (1973), "The pricing of options and corporate liabilities". Journal of Political Economy, v. 81, p. 637-659.

[11] Silva, E. L. da; Menezes, E. M., "Metodologia da Pesquisa e Elaboração de Dissertação". 4 ed. Florianópolis: Editora UFSC, 2005.

[12] ANUÁRIO CNT DO TRANSPORTE, "Passageiros-Quilômetro pagos transportados". Available at: (http://anuariodotransporte.cnt.org.br/2018/Aeroviario/4-5-2-1-/ Passageiros-Quil\%C3\%B4metro-pagos-transportados-(RPK)). Acessed in: June 10, 2019.

[13] Pindyck, R. (1991), "Irreversibility, Uncertainty, and Investment". Journal of Economic Literature, v. 29, n. 3, p. $110-1148$.

[14] Dixit, A. and R. Pindyck (1994), "Investment under uncertainty". New Jersey, USA: Princeton University Press.

[15] Lima, Gabriel A.C.; Suslick, Saul B, "Estimativa da volatilidade de projetos de bens minerais". Rem: Revista Escola de Minas, v. 59, n. 1, p. 37-46, 2006.

[16] Souza, J. C. F.; Rocha, C. H.; Souza, J. G. M., "Modelo de Opções Reais para avaliação de investimentos em novos portos e terminais portuários brasileiros". Transportes (Rio de Janeiro - Brasil), vol. 26, série 4, p. 103-115, 2018.

[17] Merton, R. (1973), "Theory of rational option pricing". Bell Journal of Economics and Management Science, v. 4, p. 141-183.

[18] Hair Jr, J. F., Anderson, R. E., Tatham, R. L., and Black, W. C., "Análise Multivariada de Dados". Bookman, Porto Alegre (RS), Brazil. (2005). 